\title{
The Cardiac Intensive Care Unit Network in Croatia
}

\section{Ana Đuzel*, Marin Pavlov, Zdravko Babić}

University Hospital Centre "Sestre milosrdnice", Zagreb, Croatia
KEYWORDS: cardiac intensive care unit, organization, Croatia

CITATION: Cardiol Croat. 2017;12(9-10):345. | https://doi.org/10.15836/ccar2017.345

*ADDRESS FOR CORRESPONDENCE: Ana Đuzel, Klinički bolnički centar Sestre milosrdnice, Vinogradska 29, HR-10000 Zagreb, Croatia. / Phone: +385-1-3787-965 / E-mail: ana29.djuzel@gmail.com

ORCID: Ana Đuzel, http://orcid.org/0000-0003-0095-2987 • Marin Pavlov, http://orcid.org/0000-0003-3962-2774 • Zdravko Babić, http://orcid.org/0000-0002-7060-8375

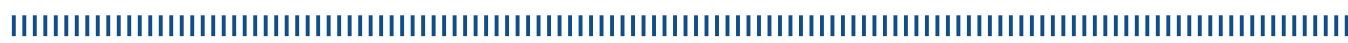

Organization and outcome of health care in general, as well as, of cardiac intensive care units (CICU) highly depends on gross domestic product (GDP). We had been witnessing evolution of CICU from point of rapid resuscitation to intervention, and finally compendious critical care. ${ }^{1}$ Authors analyze organization of CICU on national level in Croatia and compare it with economically more developed countries. Croatian GDP per capita is 35-40\% of European (EU-28) average, which groups us among economically less developed European countries. ${ }^{2}$ Data were collected from thirty-four Croatian hospitals, and analyzed during September and October 2016. ${ }^{1}$

Croatia has 5 CICU per million inhabitants with mostly 5-6 beds (range of 1-9), on average one nurse on 2.7 patients (significant variation according to hospital size) and less than 4 beds per one physician (mostly cardiologists, lesser extent during night shifts). In addition, $76.5 \%$ of ICUs had $24 / 7$ transthoracic echocardiography, 26.5\% 24/7 transesophageal echocardiography, one third without therapeutic hypothermia, and $23.5 \%$ without ECMO as available treatment.

This representative, nationwide sample of Croatian CICUs demonstrated considerable variation of key elements of structures with respect to hospital size and financial issues, what influenced following of present international guidelines. This kind of investigation revealed the space for improvement and has to be taken into account while proposing standards, reimbursement master plan, or quality assessment of national health system. ${ }^{3}$
RECEIVED:

September 242017

ACCEPTED:

September 26, 2017

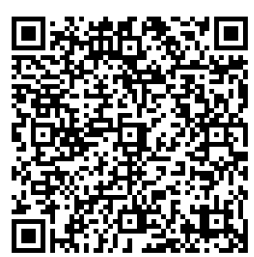

LITERATURE IIIIIIIIIIIIIIIIIIIIIIIIIIIIIIIIIIIIIIIIIIIIIIIIIIIIIIIIIIIIIIIIIIIIIIIIIIIIIIIIIIIIIIIIIIIII

1. Morrow DA, Fang JC, Fintel DJ, Granger CB, Katz JN, Kushner FG, et al; American Heart Association Council on Cardiopulmonary, Critical Care, Perioperative and Resuscitation, Council on Clinical Cardiology, Council on Cardiovascular Nursing, and Council on Quality of Care and Outcomes Research. Evolution of critical care cardiology: transformation of the cardiovascular intensive care unit and the emerging need for new medical staffing and training models: a scientific statement from the American Heart Association. Circulation. 2012 Sep 11;126(11):1408-28. https://doi.org/10.1161/CIR.0b013e31826890b0

2. Eurostat. Eurostat regional yearbook 2017. https://doi.org/10.2785/257716

3. Bonnefoy-Cudraz E, Bueno H, Casella G, De Maria E, Fitzsimons D, Halvorsen S, et al. Acute Cardiovascular Care Association Position Paper on Intensive Cardiovascular Care Units: An update on their definition, structure, organisation and function. Eur Heart J Acute Cardiovasc Care. 2017 Aug 1:2048872617724269. https://doi.org/10.1177/2048872617724269 